\title{
CHARACTERIZATION AND DRYING OF CAJA BAGASSE (Spondias mombin L.) IN A TRAY DRYER USING A FACTORIAL PLANNING ${ }^{1}$
}

\author{
ANDRÉIA SOUTO DA SILVA², EDSON LEANDRO DE OLIVEIRA ${ }^{2}$, \\ EVERALDO SILVINO DOS SANTOS ${ }^{2}$, JACKSON ARAÚJO DE OLIVEIRA ${ }^{2}$
}

\begin{abstract}
The caja (Spondias mombin L.) is used in the manufacture of ice-cream, jams, pulps, beverages being also consumed in natura. One of the most important procedures in food conservation is drying, considering that most fresh fruits contain approximately $80 \%$ of water. Food drying is used to obtain two basic aspects: (1) the economic factor; in the shipping and handling of the product; (2) at the manipulation; once dried and grinded, the material is rehydrated, at desirable levels, to formulate a new product as in ice cream, jams, yoghurts and drinks and may also be added to pasta, biscuits and other industrialized products. The aim of this study was to investigate the kinetics of caja bagasse drying in a fixed-bed tray dryer, using central composite factorial planning. The following factors were evaluated: temperature $\left(55,65\right.$ and $\left.75^{\circ} \mathrm{C}\right)$, dryer inlet air velocity $\left(3.2,4.6\right.$ and $\left.6.0 \mathrm{~m} . \mathrm{s}^{-1}\right)$ and cake thickness $(0.8,1.2$ and $1.6 \mathrm{~cm})$ where the response of the considered variable was caja bagasse moisture content (b.s.) and the results showed that the main effects and their interactions were significant at a $95 \%$ confidence level being the best condition obtained at temperature of $75^{\circ} \mathrm{C}$, velocity of $6.0 \mathrm{~m} \cdot \mathrm{s}^{-1}$ and cake thickness of $0.8 \mathrm{~cm}$.
\end{abstract}

Index terms: Caja, Fruit bagasse, Drying, Factorial planning.

\section{CARACTERIZAÇÃO E SECAGEM DO BAGAÇO DE CAJÁ (Spondias mombin L.) EM SECADOR DE BANDEJAS UTILIZANDO UM PLANEJAMENTO FATORIAL}

\begin{abstract}
RESUMO - O cajá (Spondias mombin L.) é utilizado na fabricação de sorvetes, geléias, polpas, produção de bebidas e consumo in natura. Um dos procedimentos mais importantes para a conservação de alimentos é a secagem, considerando que a maioria dos frutos frescos são constituídos de aproximadamente $80 \%$ de água. A secagem de alimentos é utilizada visando basicamente dois aspecto: o fator econômico do transporte e manuseio do produto; o material após seco e triturado é depois reidratado, em níveis desejáveis, para formulação de um novo produto como na fabricação de sorvetes, geléias, de iogurtes, de bebidas e também poderá ser adicionado em massa, biscoitos e outros produtos industrializados. O objetivo deste trabalho foi estudar a cinética de secagem do bagaço de cajá, em secador de bandejas com leito fixo, utilizando um planejamento fatorial composto central. Os fatores avaliados foram: temperatura $\left(55 ; 65\right.$ e $\left.75^{\circ} \mathrm{C}\right)$, velocidade do ar de entrada no secador $\left(3,2 ; 4,6\right.$ e 6,0 m. $\left.\mathrm{s}^{-1}\right)$ e espessura da torta na bandeja $(0,8 ; 1,2$ e 1,6 cm). A variável resposta considerada foi a umidade do bagaço (b.s). Os resultados mostraram que os efeitos principais e interações foram significativos ao nível de $95 \%$ de confiança. A melhor condição foi na temperatura $75^{\circ} \mathrm{C}$, velocidade de $6,0 \mathrm{~m} \cdot \mathrm{s}^{-1}$ e espessura de $0,8 \mathrm{~cm}$.
\end{abstract}

Termos para indexação: cajá, bagaço de frutas, secagem, planejamento fatorial.

${ }^{1}$ (Trabalho 106-11). Recebido em: 30-03-2011. Aceito para publicação em: 06-02-2012.

${ }^{2}$ Programa de Pós-Graduação em Engenharia Química - Departamento de Engenharia Química Universidade Federal do Rio Grande do Norte - Câmpus Universitário, Av. Senador Salgado Filho, s/n Lagoa Nova, CEP: 59078-970 Natal-RN/ Brasil Telefone: (84) 3215-3769 Fax: (84) 3215-3770. Emails: andreia_souto@hotmail.com; edson@eq.ufrn.br; everaldo@eq.ufrn.br; jackson@eq.ufrn.br 


\section{INTRODUCTION}

The Caja (Spondias mombin L.) plays an important role as regional fruit, mainly at Northeast region of Brazil, due to its organoleptic properties. The processing of this fruit appears as a way of conservation, taking advantage of using the production exceeding as well as avoiding season problems, (SANTOS et al., 2010).

Actually, there is a great demand for natural products mostly being derivatives from fruits. These products have been used as ingredients for food industry, as ice-cream, dairy as well as bakery products, (LIMA et al., 2004).

The state of Rio Grande do Norte has a dynamic agricultural economy, specifically with respect to irrigated tropical fruit production, which was benefitted by intense technological modernization in the 1980 (SILVA, 2008).

Some of these fruits are both perishable and seasonal. There is therefore a need for technical and economical alternatives to exploit the excess production, thereby enabling consumption and exports year-round.

Increased production, however, causes environmental concerns because of the potential impacts on natural ecosystems. The problems related to the generation of solid residues and the implications for health, the environment and quality of life, have worsened in recent decades, mainly due to the lack of institutional policies for the sector (SILVA, 2008).

The implementation of a recycling system for solid residue generated by the fruit processing industry is important, since it adds economic value to fruit bagasse, in addition reducing environmental problems resulted from this industrial activity. Moreover, processing this residue generates jobs and income for the unemployed of the state.

Among the different drying systems for food products, traditional sun drying is still the most widely used procedure worldwide, mainly with grains and seeds. Traditional open-air sun drying involves exposing the product even after physiological maturation. For food substances, normal hygiene rules preclude traditional sun drying methods. However, as a result of studies conducted at a number of research centers, a wide range of dryers have been developed, using solar, electrical, wood and oil energy sources, (HONORATO, 2002).

The present study investigates the caja bagasse drying using a convection tray dryer by using a central composite factorial planning in order to assay the influence of temperature, air-drying velocity and cake thickness on moisture content of the caja bagasse. A Fick's model is also presented.

\section{MATERIALS AND METHODS}

The raw material, caja bagasse, was a gift from the "Delícia da Fruta" company in Natal, Brazil.

The portions of bagasse were packed in plastic bags, weighed, sealed and stored at $-18^{\circ} \mathrm{C}$ in freezer at the Laboratory of Food Technology of the Federal University of Rio Grande do Norte (UFRN). For each bagasse experiment performed, the bagasse was removed for thawing at room temperature, which was previously defined to obey the same thawing condition for all the experiments, as shown in Figure 1.

\section{Characterization of caja bagasse:}

All tests were done in triplicate for in natura caja bagasse. For the dried bagasse, only the content of moisture was determined.

The following tests were performed for the physicochemical characterization of in natura caja bagasse, according to the Physical-Chemical Methods of Food Analysis of the Institute Adolfo Lutz (2008):

- $\mathrm{pH}$ - measures were taken in a potentiometer DIGIMED - DMPH - 2 in temperature condition at $25^{\circ} \mathrm{C}$;

- Titratable total acidity - This method estimates the amount of organic acids (total acidity) and indicates the astringency of the fruit. The procedure consists of performing a titration with $5 \% \mathrm{NaOH}$ solution and the results are expressed as concentration of citric acid;

- Soluble solids $\left({ }^{\circ}\right.$ Brix $)$ measured by refractometer NR-2 NR-2720 in temperature condition at $25^{\circ} \mathrm{C}$;

- Water activity measured in the Aqualab samples were triturated and analyzed at room temperature in order to observe the relation between the vapor pressure of the water in the solid and the pure water at the same temperature;

- Moisture content of sample - This method is used to determine the percentage of water in a sample by drying the sample to a constant weight. In this procedure, $5 \mathrm{~g}$ of sample are placed in an oven with forced air circulation, at temperature of $80^{\circ} \mathrm{C}$. During drying, the sample is weighed to constant weight. The moisture content is expressed as the weight loss (difference between initial and final)

\section{Study specifications}

The following independent variables were defined for the factorial planning applied in this study: temperature $(\mathrm{T})$, velocity (v) and cake 
thickness $(\delta)$, in order to determine the effect of the variables on the drying process with a minimum of experiments, to establish the variable of interest - dry basis moisture content $\left(\mathrm{U}_{\mathrm{bs}}\right)$. The planning used was $2^{3}$ factorial with five central points and axial extension of 19 assays. Table 1 shows factor levels and their coded values. STATISTICA 7.0 computer package was used for factorial planning analysis.

\section{Drying}

The caja bagasse samples were removed from the freezer and maintained at room temperature for 24 hours so that homogeneous thawing would occur. These samples were arranged in 0.8 and $1.6 \mathrm{~cm}$-thick layers onto perforated aluminum trays and placed in the dryer for 3 hours and 40 minutes, a period defined in a preliminary study.

The experiments were conducted in a convection dryer, using a sample of in natura material. The operational conditions followed the factorial planning process used.

Drying equipment

The drying system used (Figure 2) is composed of a $4 \mathrm{hp}$ blower that forces a current of air through a box with four resistors, to heat and reduce the relative humidity of the drying gas. The hot gas introduced into the dryer, in contact with the material in the tray, is discarded into the atmosphere through the top of the dryer. Temperature is controlled by a thermostat connected to a $1000 \mathrm{~W}$ resistor. Gas velocity is regulated by an escape valve and an air admittance valve.

Digital thermometers were used to measure temperature variations in the room, tray and at the outlet of the dryer. Drying air moisture at the outlet and in the room was measured using a Hygrometer. Measures of air velocity at the outlet were taken with a digital anemometer. Weight variations during processing were determined by a precision scale, accurate to two digits.

Lewis (1921) refers to Fick's law in his early studies, observed that the drying process in solids was diffusional. This idea led Sherwood (1931) to carry out studies on the drying of solids, where he proposed that moisture transfer in a solid could occur by a liquid diffusion mechanism, thereby allowing the application of Fick's law to describe the moisture transport mechanism. For simple geometries and unidirectional transfer of material, Fick's second law (Equation 1) can be written as follows:

$$
\frac{\partial \mathrm{U}}{\partial \mathrm{t}}=\frac{1}{\mathrm{r}^{\mathrm{q}}} \cdot \frac{\partial}{\partial \mathrm{r}}\left(\mathrm{D} \cdot \frac{\partial \mathrm{U}}{\partial \mathrm{r}}\right)
$$

Where:

$\mathrm{U}-$ is the instantaneous moisture content
(\% d.b. or kg water $/ \mathrm{kg}$ dry matter)

$\mathrm{D}$ - is the diffusion coefficient;

$\mathrm{r}-$ is the variable of spatial dimension;

$\mathrm{q}-$ is a shape factor for different geometries, such as rectangular $(\mathrm{q}=0)$, cylindrical $(\mathrm{q}=1)$ and spherical $(\mathrm{q}=2)$.

Carlesso et al., (2005) showed that models based on the diffusion theory can describe the profile in a form acceptable for water distribution within a given agricultural product if it is possible to correlate the geometry shape of a perfect solid, beyond the requirement of establishing a functional relationship between the diffusion coefficient, water content and temperature. Then presented the analytical solutions of Equation 1 for unidirectional variables. For flatplate (rectangular) geometry proposed Equation 2:

$$
\begin{aligned}
\mathrm{U}^{*}= & \frac{\overline{\mathrm{U}}-\mathrm{U}_{\mathrm{e}}}{\mathrm{U}_{0}-\mathrm{U}_{\mathrm{e}}}=\frac{8}{\pi^{2}} \cdot \exp \left(-\frac{\pi^{2} \cdot \mathrm{D}_{\mathrm{ef}} \cdot \mathrm{t}}{\mathrm{L}^{2}}\right) \\
& \text { Where: } \\
& \mathrm{U}^{*}-\text { is the moisture ratio; } \\
& \overline{\mathrm{U}}-\text { is the instantaneous average moisture }
\end{aligned}
$$

content (\% d.b. or $\mathrm{kg}$ water $/ \mathrm{kg}$ dry matter);

$\mathrm{U}_{\mathrm{e}}$ - is the equilibrium moisture content ( $\%$ d.b. or $\mathrm{kg}$ water/ $\mathrm{kg}$ dry matter);

$\mathrm{U}_{0}-$ is the initial moisture content (\% d.b. or $\mathrm{kg}$ water/kg dry matter);

$\mathrm{D}_{\text {ef }}$ - is the effective diffusivity;

$\mathrm{L}-$ is the layer thickness for the flat-plate;

$\mathrm{T}-$ is the variable time.

The solution of the Equation 1 results in an infinite series whose terms decrease rapidly for long drying times (PARTY, 1993). Therefore, only the first term of the series was used in the present study, corresponding to the exponential term of Equation 2.

\section{RESULTS AND DISCUSSION}

\section{Physicochemical characterization}

The physicochemical characterization of raw materials was carried out with in natura caja bagasse and the results are presented in Table 2.

The results presented in Table 2 reveal that the bagasse of caja shows very high moisture content and water activity. Thus, the product drying ensures a longer shelf life, since the high water activity is conducive to the growth of microorganisms. The $\mathrm{pH}$ and acidity values indicate that the product is acid, (ADOLFO LUTZ, 2008). Comparing the results in Table 2 with the literature, there is almost no 
significant variations between the fresh fruit and bagasse.

Analysis of experimental assays using factorial planning

Analysis of the results obtained for temperature, velocity and thickness, having dry basis as response, was conducted using statistical methods and Statistica 7.0 software, according to central composite factorial planning, whose planning matrix is illustrated in Table 1.

Figure 3 shows the main effects and interactions of the independent variables, having dry basis moisture for a quadratic model as response, considering inter-variable interactions with a confidence limit of $95 \%$. The data were obtained considering the pure error. The Pareto diagram (SILVA, 2008) shows that thickness $(\delta)$ was the factor that exerted the greatest influence, with an estimated effect of approximately 32.3 . This may be due to the fact that drying time was fixed at 220 minutes. This positive sign indicates that cake thickness facilitates caja bagasse drying. One possible explanation would be the lower resistance to heat and mass transfer when smaller thickness is used.

According to Montgomery (2008), even though the main effects and their interactions are significant, the independent variables should not be analyzed in an isolated way. According to Figure 3, and based on the significant effects, Silva (2008) proposed the following model for the process under study:

$$
\hat{y}=0,04-0,46 \cdot T-0,44 \cdot v+0,86 \cdot \delta+0,36 \cdot T^{2}+0,16 \cdot v^{2}+0,74 \cdot \delta^{2}+0,36 \cdot T \cdot v-0,48 \cdot T \cdot \delta-0,70 \cdot v \cdot \delta
$$

A summary of regression analysis results for all the response variables is shown in Table 3.

Analysis of variance (ANOVA) (Table 3) shows that the proposed model is statistically significant at a $95 \%$ confidence level, since the calculated F value is 3.8 times higher than its tabulated counterpart (3.18). However, ANOVA also demonstrates that the proposed model is not useful for making predictions, given that the ratio between calculated and tabulated $\mathrm{F}$ for the lack of fit and pure error is much higher than 1 (around 11.83 times).

The coefficient of determination $\left(\mathrm{R}^{2}\right)$ was approximately $92 \%$, indicating that the model is able to explain this percentage of total variation from the mean.

For analysis of drying parameters it was observed response surfaces in order to detect the optimum point in the process and obtain signs that a quadratic model provides a good representation of the relationship between the response $\left(\mathrm{U}_{\% \text { d.b. }}\right)$ and the factors under study.
Figure 4 shows the response surface for dry basis moisture as a function of temperature $(\mathrm{T})$ and thickness $(\delta)$ for caja bagasse at the central point.

Figure 4 illustrates the optimum region for reducing caja bagasse moisture as a function of temperature and thickness at the central point. It can be observed that the optimum point for bagasse drying was at a temperature of $75^{\circ} \mathrm{C}$ and thickness of 0.8 $\mathrm{cm}$. These results show that the best condition for caja bagasse drying was at a temperature of $75^{\circ} \mathrm{C}$, velocity of $6.0 \mathrm{~m} / \mathrm{s}$ and cake thickness of $0.8 \mathrm{~cm}$ for a time of 220 minutes.

\section{Drying curves}

The kinetics of caja bagasse drying in a fixedbed dryer was studied. The following operational variables were analyzed: temperature, drying air velocity and cake thickness. Figure 5 ( $a$ and $b$ ) shows the kinetic behavior for temperatures of $55^{\circ} \mathrm{C}$ and $75^{\circ} \mathrm{C}$. At lower temperatures drying did not achieve constant moisture under these operational conditions. Figure 5 also shows the similar kinetic behavior of the drying curves, represented in the non-dimensional form of the moisture ratio $\left(\mathrm{U}^{*}\right)$, as a function of drying time $(\mathrm{t})$.

The loss of moisture in the processed material is much faster at the onset of drying. In 60 minutes of drying at a temperature of $55^{\circ} \mathrm{C}$ the moisture ratio $\left(\mathrm{U}^{*}\right)$ was $0.22 \%$ d.b. while at temperature of $75^{\circ} \mathrm{C}$ it was $0.07 \%$ d.b.. Moura et al., (2001) also found similar results and report that the time required to dry caja at lower temperatures $\left(35^{\circ} \mathrm{C}\right.$ and $\left.40^{\circ} \mathrm{C}\right)$ was twice the time used at a higher temperature $\left(65^{\circ} \mathrm{C}\right)$. It is also observed that equilibrium moisture content was not achieved in 220 minutes of process. Sousa et al., (2003) showed the determination of drying curves and the variation of water activity from guava pretreated by osmotic dehydration with and without use of vacuum during the drying time, and monitor variations in texture and color attributes during drying.

Based on curve linearization in Figure 5, the effective diffusivity $\left(D_{\text {ef }}\right)$ calculated was $6.772 \times 10^{-9} \mathrm{~m}^{2} / \mathrm{s}$. Similar results were found by Matias et al., (2005), who showed effective diffusivity $\left(\mathrm{D}_{\mathrm{ef}}\right)$ values between $1.62 \mathrm{x}$ $10^{-9}$ and $2.99 \times 10^{-9} \mathrm{~m}^{2} / \mathrm{s}$ in caja and guava bagasse drying at temperatures between $55^{\circ} \mathrm{C}$ and $65^{\circ} \mathrm{C}$. 


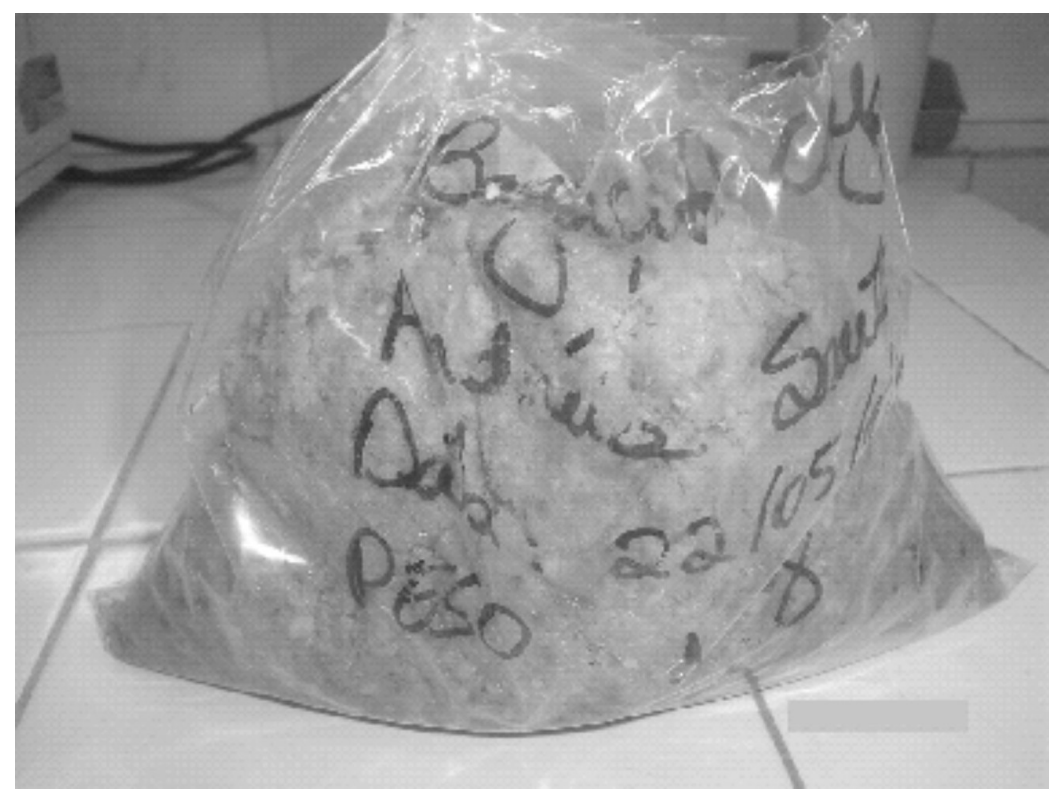

FIGURE 1 - In natura caja bagasse in the thawing process.

Temperature control

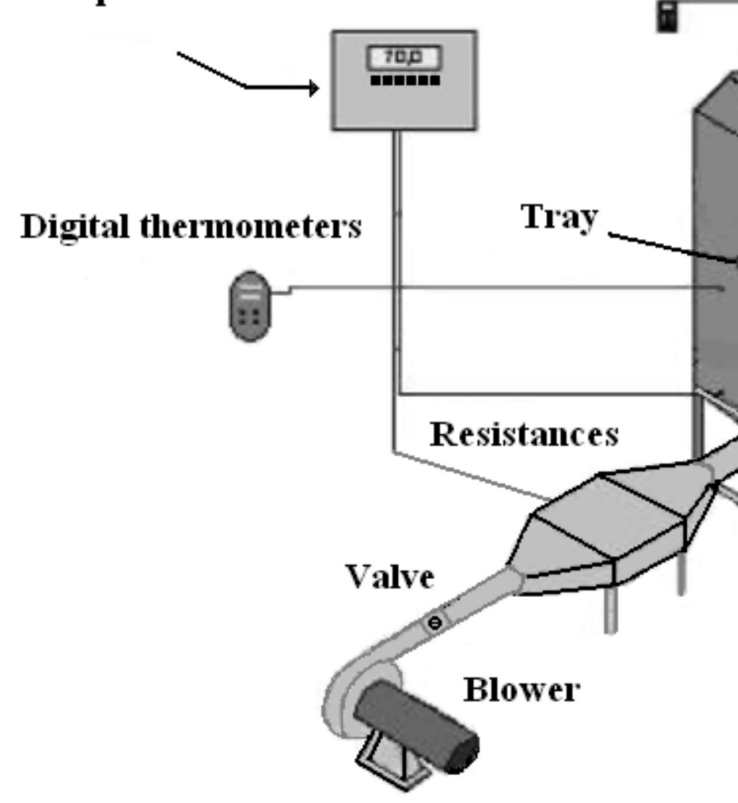

\section{Hygrometer}

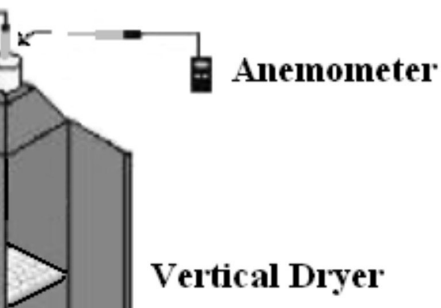

FIGURE 2 - Drying system diagram - convection tray dryer. 


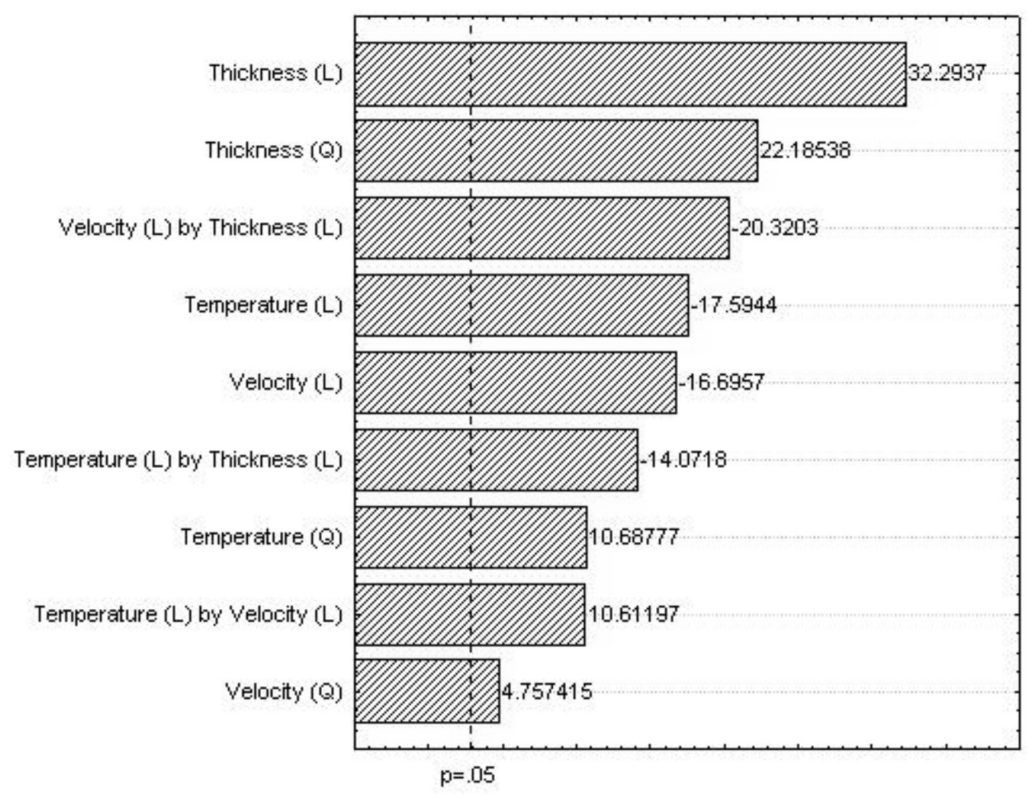

FIGURE 3- Pareto diagram of central composite planning showing the influence of the factors studied.

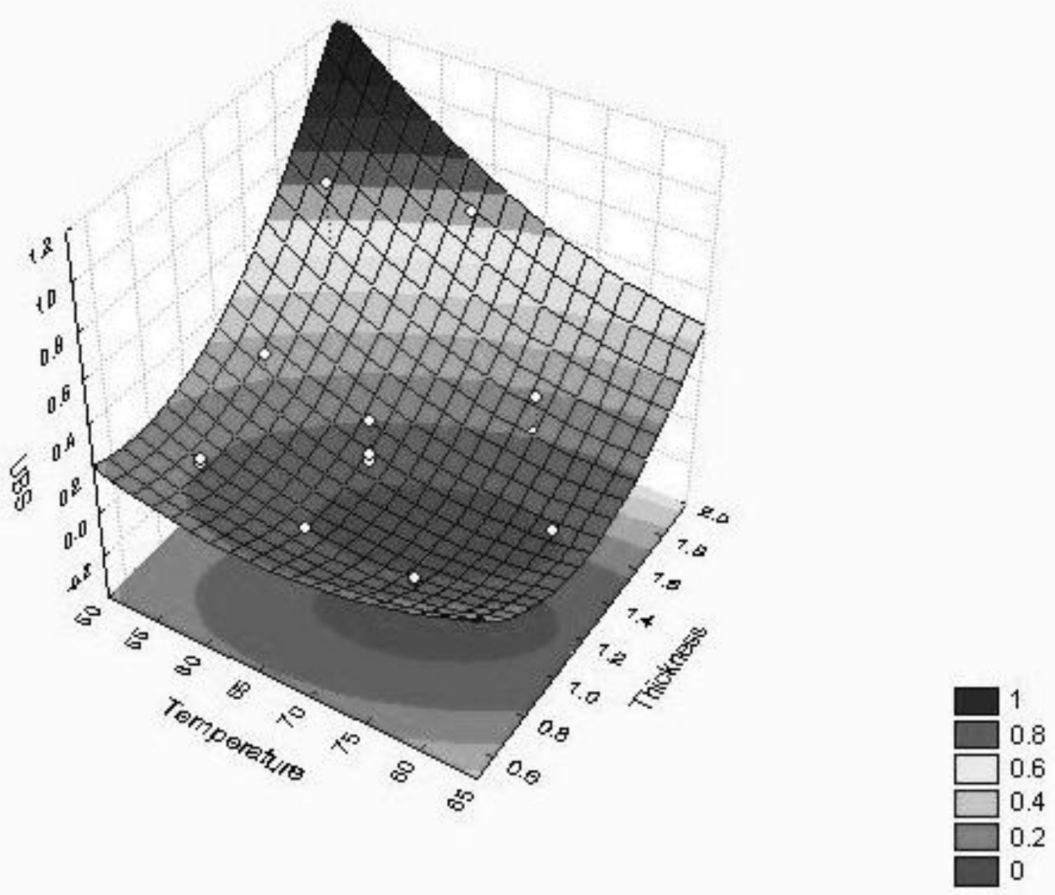

口

FIGURE 4 - Dry basis moisture $\left(\mathrm{U}_{\% \text { d.b. }}\right)$ as a function of temperature $(\mathrm{T})$ and thickness $(\delta)$ for caja bagasse at the central point- velocity. 

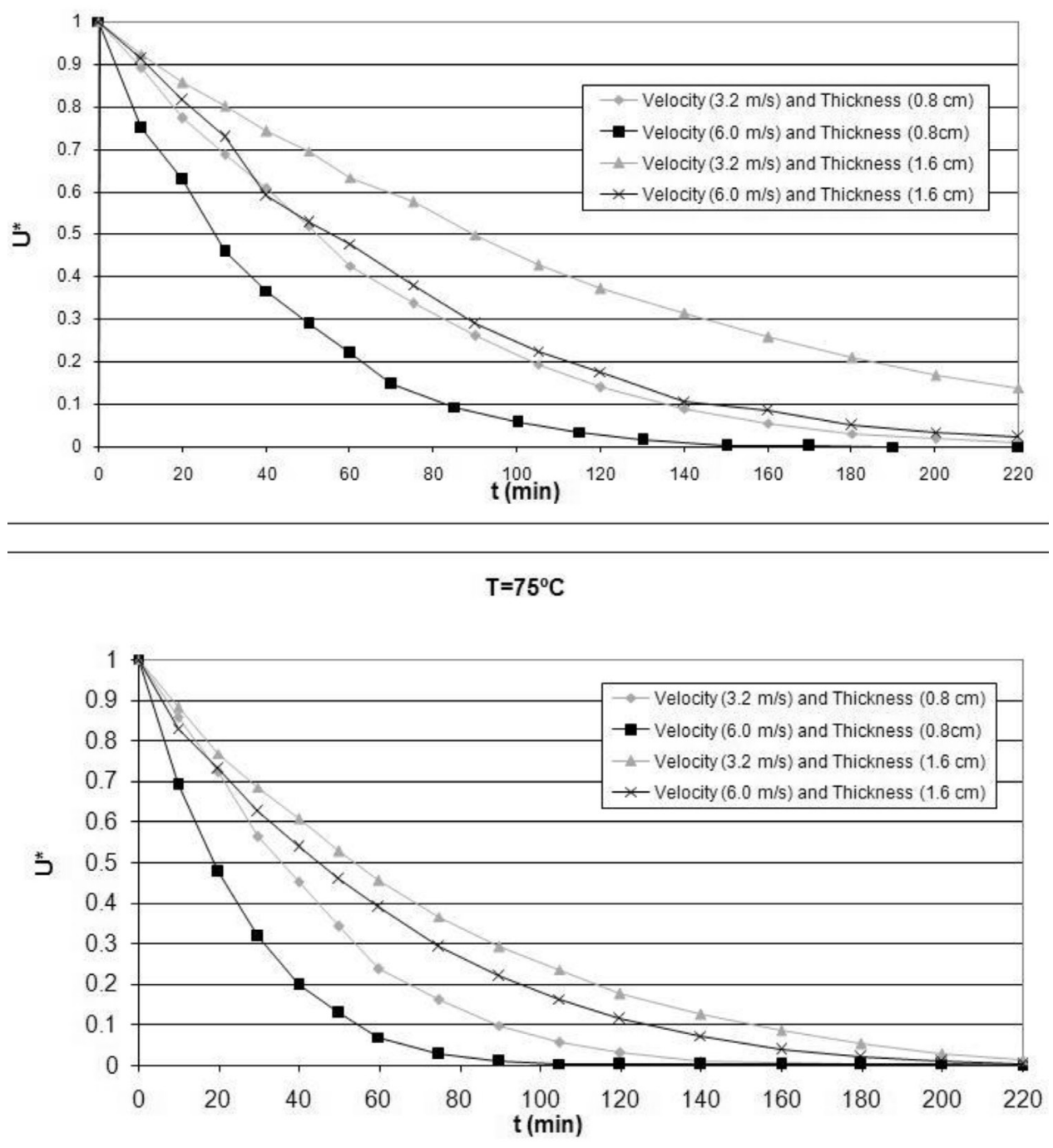

FIGURE- 5 - Kinetics of caja bagasse drying represented as moisture ratio $\left(\mathrm{U}^{*}\right)$ for two thicknesses and two drying air velocities at temperature of $55^{\circ} \mathrm{C} \mathrm{(a)} \mathrm{and} 75^{\circ} \mathrm{C}(\mathrm{b}$ ). 
TABLE 1 - Factor levels and their coded values for caja bagasse drying.

\begin{tabular}{|c|c|c|c|c|c|c|c|}
\hline Ensaio & $\mathbf{T}_{\text {Coded }}$ & $\mathbf{T}_{\text {Real }}$ & $\mathbf{V}_{\text {Coded }}$ & $\mathbf{V}_{\text {Real }}$ & $\delta_{\text {Coded }}$ & $\delta_{\text {Real }}$ & $\mathbf{U}_{\text {Final(\% } \% \text { d.b. })}$ \\
\hline $01(01)$ & - & 55 & - & 3,2 & - & 0,80 & 0,099 \\
\hline $02(17)$ & + & 75 & - & 3,2 & - & 0,80 & 0,009 \\
\hline $03(16)$ & - & 55 & + & 6,0 & - & 0,80 & 0,120 \\
\hline $04(04)$ & + & 75 & + & 6,0 & - & 0,80 & 0,013 \\
\hline $05(14)$ & - & 55 & - & 3,2 & + & 1,60 & 0,800 \\
\hline $06(13)$ & + & 75 & - & 3,2 & + & 1,60 & 0,215 \\
\hline $07(15)$ & - & 55 & + & 6,0 & + & 1,60 & 0,205 \\
\hline $08(05)$ & + & 75 & + & 6,0 & + & 1,60 & 0,048 \\
\hline $09(11)$ & 0 & 65 & 0 & 4,6 & 0 & 1,20 & 0,044 \\
\hline $10(06)$ & 0 & 65 & 0 & 4,6 & 0 & 1,20 & 0,016 \\
\hline $11(09)$ & 0 & 65 & 0 & 4,6 & 0 & 1,20 & 0,025 \\
\hline $12(03)$ & 0 & 65 & 0 & 4,6 & 0 & 1,20 & 0,017 \\
\hline $13(08)$ & 0 & 65 & 0 & 4,6 & 0 & 1,20 & 0,008 \\
\hline $14(10)$ & - & 55 & 0 & 4,6 & 0 & 1,20 & 0,306 \\
\hline $15(12)$ & $\alpha$ & 81,8 & 0 & 4,6 & 0 & 1,20 & 0,055 \\
\hline $16(19)$ & 0 & 65 & - & 3,2 & 0 & 1,20 & 0,202 \\
\hline $17(18)$ & 0 & 65 & $\alpha$ & 6,952 & 0 & 1,20 & 0,048 \\
\hline $18(07)$ & 0 & 65 & 0 & 4,6 & - & 0,80 & 0,014 \\
\hline $19(02)$ & 0 & 65 & 0 & 4,6 & $\alpha$ & 1,87 & 0,678 \\
\hline
\end{tabular}

TABLE 2 - Results of physicochemical analysis for the in natura caja bagasse.

\begin{tabular}{|l|c|}
\hline \multicolumn{1}{|c|}{ Analysis } & In natura caja bagasse \\
\hline Moisture b.u (\%) & 83.3 \\
\hline Water activity $\left(\mathrm{a}_{\mathrm{w}}\right)$ & 0.988 \\
\hline $\mathrm{pH}$ & 3.1 \\
\hline Soluble solids $\left({ }^{\circ}\right.$ Brix) & 11.2 \\
\hline Titratable total acidity mg citric acid / 100 mg & 1.5 \\
\hline
\end{tabular}

TABLE 3 - Regression analysis results for temperature, velocity and thickness.

\begin{tabular}{|c|c|c|c|c|}
\hline Source of variation & Quadratic sum & Degrees of freedom & Quadratic media & $\mathrm{F}$ \\
\hline Regression & 0.8383 & 9.00 & 0.0931 & 11.95 \\
\hline Residue & 0.0701 & 9.00 & 0.0078 & 74.03 \\
\hline Lack of fit & 0.0694 & 5.00 & 0.0139 & \\
\hline Pure error & 0.0007 & 4.00 & 0.0002 & \\
\hline Total & 0.9084 & 18.00 & & \\
\hline
\end{tabular}




\section{CONCLUSIONS}

The diffusion model fit the experimental results of caja bagasse drying well at temperatures between $55^{\circ} \mathrm{C}$ and $75^{\circ} \mathrm{C}$, velocity of 3.2 and $6.0 \mathrm{~m} / \mathrm{s}$ and bed thickness of 0.8 and $1.6 \mathrm{~cm}$ with a time of 120 minutes. The results show that the diffusional model based on Fick's law (Equation 2) satisfactorily describes the drying process. According to the results shown in Figures 5 and 6, the best drying condition was at a temperature of $75^{\circ} \mathrm{C}$, air velocity of 6.0 $\mathrm{m} / \mathrm{s}$ and cake thickness of $0.8 \mathrm{~cm}$, where the drying constant calculated was $6.772 \times 10^{-9} \mathrm{~m}^{2} / \mathrm{s}$. All the main effects and their interactions were significant at a confidence level of $95 \%$. In this case, the most significant factor was cake thickness, followed by drying air velocity. The quadratic model fit experimental data well, with $\mathrm{R}^{2}=92 \%$. The model was statistically significant, but not predictive. Analysis of the response surface showed that the best condition for caja bagasse drying was at a temperature of $75^{\circ} \mathrm{C}$, velocity of $6.0 \mathrm{~m} / \mathrm{s}$ and cake thickness of 0.8 $\mathrm{cm}$ for a time of 220 minutes. The results obtained by response surface methodology (RSM) are in agreement with process kinetics.

\section{ACKNOWLEDGMENT}

The authors thank CNPQ - Conselho Nacional de Desenvolvimento Científico e Tecnológico for the financial support of this study.

\section{REFERENCES}

CARLESSO, V. O.; BERBET, P. A.; SILVA, R. F.; VIANNA, A. P.; DIONELLO, R. G. Secagem de sementes de maracujá em camada delgada. Revista Brasileira de Fruticultura, Jaboticabal, v. 27, n. 3, p. 444-448, 2005.

HONORATO, G.C. Aproveitamento do cefalotórax de camarão na produção de farinha para complemento alimentar. 2002. 87f. Dissertação (Mestrado em Engenharia Química) - Centro de Tecnologia, Departamento de Engenharia Química, Programa de Pós-Graduação em Engenharia Química, Universidade Federal do Rio Grande do Norte, Natal, 2002.

INSTITUTO ADOLFO LUTZ. Métodos físicoquímicos para análise de alimentos. 4.ed. São Paulo: Instituto Adolfo Lutz, 2008.

LEWIS, W. K. The rate of drying of solids materials. The Journal of Industrial and Engineering Chemistry, Washingyon, v.13, n.5, p.427-432,1921.
LIMA, A. S.; FIGUEIREDO, R. W.; MAIA, G. A.; LIMA, J. R.; SOUSA, P. H. M. Estudo da estabilidade de melões desidratados obtidos por desidratação osmótica seguida de secagem convencional Revista Brasileira de Fruticultura, Jaboticabal, v. 26, n. 1, p. 107-109, 2004.

MATIAS, M. F. O.; OLIVEIRA, E. L.; GERTRUDES, E.; MAGALHÃES, M. M. A. Use of fibres obtained from the cashew (anacardium ocidentale $\mathrm{L}$ ) and guava (psidium guayava) fruits for enrichment of food products. Brazilian Archives of Biology and Technology, Curitiba, v.48, p. 143-150, 2005. Número especial.

MONTGOMERY, D. C. Design and analysis of experiments. 7.ed. New York: Wiley, 2008.

MOURA, R. S. F.; ALMEIDA, F.A.C.; GOUVEIA, J.P.G.; SILVA, M.M.; FIGUEIREDO NETO, A. Efeito da temperatura e da velocidade do ar na secagem de caju. In: CONGRESSO BRASILEIRO DE ENGENHARIA AGRÍCOLA, 30., 2001, Foz do Iguaçu. Anais...

PARTY, M. Selection of mathematical models for drying grain in thin - layers. Journal of Agricultural Engineering Research, London, v.54, p. 339-352,1993.

SANTOS, M. B.; CARDOSO, R. L.; FONSECA, A. A. O.; CONCEIÇÃO, M. N. Caracterização e qualidade de frutos de umbu-cajá (Spondias tuberosa X S mombin) provenientes do Recôncavo Sul da Bahia.

Revista Brasileira de Fruticultura, Jaboticabal, v. 32, n. 4, p. 1089-1097, 2010.

SHERWOOD, T. K. Aplication of the theorical diffusion equations to the drying of solids. Transations American Institute of Chemical Engineering, London, v.27, p. 310-333, 1931.

SILVA, A.S. Avaliação da secagem do bagaço de cajá usando planejamento fatorial composto central. 2008. 78f. Dissertação (Mestrado em Engenharia Química) - Centro de Tecnologia, Departamento de Engenharia Química, Universidade Federal do Rio Grande do Norte, Natal, 2008.

SOUSA, P. H. M.; MAIA, G. A.; FILHO, M. S. M. S.; FIGUEIREDO, R. W.; SOUZA, A. C. R. Goiabas desidratadas osmoticamente seguidas de secagem em estufa. Revista Brasileira de Fruticultura, Jaboticabal, v. 25, n. 3, p. 414-416, 2003. 